\title{
The Saddle-Shaped Thoughts Transformation of Mao Zedong in the Agrarian Reforms of China
}

\author{
Ping Sun \\ School of Marxism \\ North China Electric Power University \\ Beijing, China 102206
}

\begin{abstract}
The thoughts transformation of Mao Zedong in the land ownership policies can be divided into three stages and was saddle-shaped. First, the traditional Chinese Great Harmony, his life-long guiding principle upon the various policies, decided his preference for the public land ownership when he was still young. Secondly, as a pragmatist, Mao transformed his thought to adopt private ownership policy for more than twenty years (1930-1953). Thirdly, when Mao Zedong possessed the authority over the country, he released the general line, started the Great Leap Forward, and proposed the People's Communes to realize his idealized target, a purer communist country, which resulted in a great disaster. The whole process of Mao Zedong's thoughts transformation was a result of his compromise between the ideal in his mind and the reality of the society.
\end{abstract}

Key words: Saddle-shaped; Thoughts transformation; Land ownership

Mao Zedong thought has aroused heated debates both domestic and abroad. The contribution of his thought to China's revolution, construction and reform as one of the guiding principles is one important concern (Wang Weiguang, 2014). His preference of humility posed by Confucius, and his idea of working with an eye toward harmony and not become arrogant, are all found to be the requisites for qualified leaders (Lin \& Clair, 2007). On the other hand, critical comments on him, particularly on his wrong decision in the Great Leap Forward is a forever-lasting topic in many papers (Karl, 2010; Selden, 2006), though there is still the neutral wording of his initial good intention "to change as quickly as possible the visage of poverty and backwardness, and to truly advance and strengthen China to establish its place among the world's nations"(Dirlik, 2012). However, Mao's wrong decision in the Great Leap Forward was not sudden but natural, which is less disclosed and will be the focus of the present paper.

The key to the Chinese revolution is undoubtedly in the hands of the peasants, and the key problem of the peasants is the land. This is Mao Zedong's comprehension of the contemporary China and his admiration of the "innate wisdom of the peasantry" and his "professed ardent faith in the revolutionary creativity of the rural masses"(Nick, 2004). Having realized the importance of these two "keys"in the whole process of the Chinese revolution, how to solve the land problems of the peasants so as to arouse their aspiration for the revolution became a perpetual concern in Mao's policies. However, Mao Zedong's thoughts on agrarian policies in the rural areas of China seemed to be a detour, starting from "land nationalization"and ending with the implementation of the collective communes, with a middle insistence on the privateowned land system. This corresponded to three stages and was much saddle-like.

The first stage refers to the period of the Agrarian Revolution when Mao Zedong was still a young man. At that time, Mao adhered to public ownership of the land, under the influence of 
the traditional Chinese Great Harmony and the policies propelled by the Comintern. They shouted the slogan of "Land Nationalization", which was directly taken from the Soviet Union, and was in essence transferring the land to public ownership.

The second stage was between 1930 and 1953, consisting of three periods (Hu Chan, 2010): 1930-1937; from 1937 to the beginning of 1946; from the first half of 1946 to June, 1953. During these twenty-three years, Mao Zedong changed his mind to adopt the policy of private land ownership. This long stage witnessed the vital change of Mao Zedong upon the land reform in the rural areas of China, that is, from his adherence to the public ownership to his adoption of the view of privatization. Although there was some vacillation in his views, his main insistence on privatization was consistent and it was executed successfully in practice. History proved that giving the land ownership to the peasants themselves provided a firm foundation and a beneficial environment for the following Anti-Japanese War and the Liberation War.

The third stage started from the socialist reform of 1953 and lasted until the death of Mao Zedong. During this period, Mao exercised his authority to a certain degree, articulating his desire for a "purer and purer" commune being "large in size and collective in nature". Because of this thought, many actions followed, with "nearly all agricultural land becoming publicly owned and 96.3 percent of households joining agricultural cooperatives" (Wang Weiguang, 2014). Even the small vegetable gardens around the peasants' houses were confiscated, aiming to eliminate the last track of capitalism. Consequently, the peasants were completely forced to step on the road to the public ownership of the land.

Looking back at Mao's thoughts transformation upon the agrarian policies, we attempt to ask and answer the following questions: What is the deep reason for his preference for the public land ownership? What are the specific policies adopted at the three stages? What caused his change of mind? And what are the consequences of his thoughts transformation?

\section{THE INFLUENCE OF THE TRADITIONAL CHINESE GREAT HARMONY}

To talk about Mao Zedong's thoughts, we need to trace it back to the traditional Confucian Great Harmony, an inherent culture of China. It is so influential that many writers quoted it to cast lights on the development of the society. Some of them are the following: the classical Chinese Confucian work The Book of Rites, Zhang Lu's Five-dou-grain Taoism, Tao Yuanming's Peach Blossom Spring, and Kang Youwei's On Great Unity. Furthermore, Liang Qichao, Sun Zhongshan and others enthusiastically introduced the Chinese people to their fresh ideas, which, in essence, were the result of a combination of both the western thoughts on socialism and communism and the Chinese Great Harmony (Wang Lei, 2012).

To know what is Great Harmony, we can read the description and elaboration given by The Book of Rites:

To realize the ideal society, people must possess the following thoughts. Those qualified people should be elected to be leaders, and honesty between people and harmony among people should be given adequate emphasis. Therefore, it is not enough to take care of only one's own parents and one's own children. The ideal state is to guarantee all the old people an easy life, to make all the adults do their best for the society, to give all the children a happy childhood, and to ensure all those disabled people a living. Men should have their jobs and women should be married at a proper age. Those who throw away the disliked things are hated, because keeping it is not just for oneself. Those who do not work all their best are also disliked, because we work not only for ourselves. As a consequence, nobody will conspire, nobody will steal, and 
people need not to lock their door when they are going out. This is called "The Great Harmony".

This definition of the "Great Harmony" is in essence the idealization of egalitarianism by the people of an agrarian society. At that time, the society was vacillating violently, and people hoped that under this poor condition, a harmonious and safe society could be founded without destroying the original traditions (Wang Lei, 2012).

The "Great Harmony" was also represented in The Heavenly Land System by the Taiping Heavenly Kingdom, in which they claimed to change the ownership of the land to God instead of people. The specific principles were the following: Nobody can own something, because everything belongs to God; People are equal to get the same amount of land or goods. This is the abstract egalitarianism. Another example was Kang Youwei, who combined the Confucian Great Harmony and The Three Worlds' Theory with the western utopian socialism, and created a harmonious society for the future (Liu Mei, 2011). In this united, equal, and harmonious society, there was no private property, no identity differentiation, no rich or poor distinction, no ethnic problem, and no gender differences (Xu Quanxing, 2003: 64). This was also emphasized in The Three Principles of People proposed by Sun Zhongshan (1956: 798): The purpose of livelihood by Guo Mindang is to divide social property into average parts, so livelihood here equals to socialism.

All these beautiful wishes based on the Great Harmony attracted Mao Zedong a lot. He harbored this thought in his mind and applied the theory to practice first in his "New Village Plan", and then in his advocating and exercising of the large-sized and public-natured People's Communes.

In 1917, Mao expressed his great admiration of the ideas of the Great Harmony in A Letter to Li Jingxi, saying "What is implied in the Great Harmony is our great ideal. We should compose our morals, do good deeds, and expose our ideas in writing, so as to contribute to this world. We should be mercifully benevolent to those base people". His thought was further concreted in 1919 into the "New Village Plan", with the idea of "part-work and part-study". In this year, he published his On Students'Work, suggesting a new village with the simultaneous functions of school, family and society. In this new society, we will have all sorts of organizations and facilities like the kindergarten, nursing home, school, library, bank, farm, factory, shopping center, theatre, garden, museum, as well as the council (The Earlier Works of Mao Zedong, 1990: 454).

Mao Zedong's admiration and practicing of the ideas of the Great Harmony is a result of his combination of both the Confucian egalitarianism and communism in Marxist Theories. This was based on the assumption that "If we combine several families, we can have one new society", and in this new society, people may work together in planting vegetables, farming, planting trees, raising livestock, rearing silkworms, and raising chickens and fish, etc. This corresponded greatly to what he executed in the People's Commune during the Great Leap Forward. As a matter of fact, the pursuit of equality and egalitarianism can be perceived as the main element in all of Mao's decisions throughout his life.

\section{THE THREE STAGES OF MAO ZEDONG'S THOUGHTS TRANSFORMATION}

\section{Land Nationalization}

To begin with, the transferring of the land to public ownership started right after the establishment of the Communist Party of China. The Fifth National Congress of the CPC pointed out clearly that "Land Nationalization is the basic principle of the Party Program upon the 
peasants". And the August Seventh Conference, for the first time, made "Land Nationalization"their slogan, which corresponded to what Mao pursued of the Great Harmony in his young age.

Furthermore, Mao Zedong expounded his view of land nationalization in several of his works, such as The Agrarian Law of Jinggangshan, and The Agrarian Law of Xingguo (a county of Jiangxi Province). In addition, he claimed that law should be used to enforce its exercising process.

Since time immemorial, Chinese intellectuals had been accustomed to the static thinking pattern formed on the undeveloped commodity economy in an agrarian society, and their pursuit of a great harmonious society was just to put the society into a static position. This was a severe type of utopian and egalitarian society and it had been evidenced by the history of the social development as well as the practices of the revolutionists and reformists (Wen Rui, 2004: 310).

\section{The Stage of Land Privatization}

The failure of the first revolution frustrated Mao to a certain degree and made him realize once more that to mobilize the mass, their basic problem must be resolved, that is, making the peasants possess the land ownership. In a new situation under the influence of the Comintern, he started to think about the previous land policies adopted by the Communist Party of China. Then taking the typical Chinese features into consideration, he explored tentatively to find the practical and effective land policies.

In October, 1930, when reviewing The Resolutions on the Agrarian Issues, Mao Zedong pointed out that it was not proper to announce the public ownership without a serious thinking, because this policy was not fit for the requirements of the rural areas in the contemporary China.

On February 8, 1931, based on the third plenary session of the $6^{\text {th }}$ National Congress, the Communist Party of China in the Red Area sent out a formal document, Land Issues and the Anti-Rich peasants Policies, addressing that "the peasants' aspiration was confined to a desire for the use of the land and the right to possess the land". Therefore, in the present situation of so many complex conflicts, "it is a wise decision to give the peasants their land ownership".

On February 28, 1931, Mao Zedong, on behalf of the Chief Director of the Political Department of the Military Committee of the Central Revolution, wrote a letter to the Soviet Government, pointing out the main problem in the Red Area was the land ownership. The briefing was the following: Land used to belong to the Soviet government and the peasants only had the right to use it. The land was divided frequently, but the feel of non-ownership of the land made the peasants feel not safe enough. He pleaded earnestly to the Soviet Government that a decree should be released, with the announcement that "What was distributed to the peasants in the past should be regarded as their own private land, and nobody can invade it. From now on, their land was their life-long property. They have every right to rent it or to sell it. What they would get from it was also their own property, except the required taxes from the government" (The Earlier Works of Mao Zedong,1990:454).

In 1935, around the Wayaobao Conference, Mao Zedong made it clear that lawful land owned by the peasants should be protected, and public ownership should not be mentioned again until the victory of the revolution of China. From that time on until the end of agrarian reform, the Communist Party of China issued The Principles of Land Law in China and Land Law of The 
People's Republic of China and etc, . They shared one point: What was distributed to the peasants should be regarded as their private property, and the government should give them the certificate of land ownership, so the peasants will possess the rights to manage the land, to buy or sell the land, to rent the land to others, or even to transfer the ownership of the land (Liu Mei, 2011).

Mao Zedong diverged from the tradition of Marxist thoughts and socialists' views to enact a series of policies to guarantee the peasants the right to own the land, like confiscating the land of the feudal landlords to give it to the peasants. This was always regarded as one effective means of solving the land problem in China, or in other words, an application of the Marxist theory into the practice of China (Long Guanhua, 2002). However, the eradication of the feudal exploitation and the real solution of the agrarian issue were after the Directions on May Fourth, 1946, whose aim was to enact the policy of "any farmer should have his own land". This goal was finally realized in The Principles of Agrarian Law, issued between July and September, 1947, claiming to abolish the feudal and semi-feudal land policy system, so as to achieve the farmer-as-owner-of-the-land purpose (Xue Lili, 2010).

After several years of the practice of the Agrarian revolution, Mao Zedong comprehended deeply of the conservatism and selfishness of the peasants. They are petty producers and private-owners, so without realizing the decisive role of land-socialization in their economy constructing process, they cannot keep from seeking for the unobtainable future of capitalism. Therefore their real purpose in participating in the revolution was to get the land-ownership. Guarantee them the desired right, their enthusiasm would last, otherwise, they would lose interest in it.

\section{The Stage of Public Land Ownership}

Since the year 1953, when the Communist Party of China put forward the directions for the transitional period, terminating the private land ownership was started formally. The land policies for the rural areas in China entered the historical significant period of "collective ownership, unified management". And "people's communes throughout the country" in the Great Leap Forward was a typical representative of Mao Zedong's thoughts of public ownership of the land. He became "the eloquent proponent of the course of gradual voluntary cooperation from mutual aid teams to elementary cooperatives to advanced co-operatives" (Selden, 2006).

In 1955, when the small-sized agricultural cooperation was in its high tide, Mao Zedong started to imagine a large-sized people's communes. He gave his explanation as follows: The smallsized agricultural cooperatives have few people, little land, and little funds, so large-scaled production cannot be managed and machines cannot be used. This will not give motive to the productive forces. Therefore, more large-scaled, multi-managed cooperative communes should be founded (Mao Zedong, 1977:257-258).

In August, 1958, the Beidaihe Conference of the Communist Party of China released the Resolutions on Founding People's Communes by the Central Committee of the Communist Party of China, with the following main claims:

Small-sized agricultural cooperatives with dozens or even hundreds of families are no longer fit for the present situation in China. It is of great necessity to cooperate beyond the boundaries of communes, towns, or even counties. A commune based on the codevelopment of agriculture, forestry, animal husbandry, subsidiary business, and fisheries and the cooperation of workers, farmers, students, businessmen, and soldiers, is of great urgency. This kind of commune will lead the peasants to the smooth road of 
constructing socialism and further help them to have a gradual transition to communism.

To Mao Zedong, this large-sized People's communes not only facilitate collective production, but also encourage the complete abolishing of the traditional family-centered, interestoriented producing system. Mao held the belief that family was the product of privateownership, which was not beneficial to the right allocation distribution in a communist country (Zhang Fang, 2012). People's communes made the transition of the social structure possible. The commune's final purpose was to realize a public-centered system of "the ownership by all people" so as to lead the people to a "happier collective life". Within this commune, people's basic necessities and services can be provided.

But this pattern of people's commune was proved to be a complete failure. After the reform and opening policy of China, household contract responsibility system with remuneration linked to output was preferred to the people's commune. Because the latter only "constrained people but not guarantee their rights" (Qing Hui, 2010) and at the same time it was wasteful and ineffective, while the former system, which seemed to be a backward, promoted the development of the rural areas, improved the peasants' life, and paved the way for the subsequent economic reforms in big cities.

\section{WHAT CAUSED MAO ZEDONG TO TRANSFORM HIS THOUGHT}

It is commonly agreed that Mao Zedong's decision of a rapid development by exercising the land reform in the rural areas of China led to exaggerated claims and the collapse of planning, which resulted in massive famine. From various perspectives, Liu Dejun (2016) generalized the four causes of Mao Zedong's wrong decisions: The influence of the traditional social ideas both domestic and abroad; The misunderstanding of Marxist theories; The changes of the international situation as well as the situation in China; His personal misunderstanding of the ideal pattern.

However, Mao's decision of public ownership was not sudden, which can be traced back to his earlier thought. "The New Village Plan" proposed by Mao Zedong in the earlier time was obviously public-centered. Though it died away for its utopian characteristics, the prospect of an ideal society was still kept in Mao's mind. After he became a firm advocator of Marxism, he started to combine the traditional Chinese Great Harmony with the ideal communism. He firmly believed that under the right theoretical guidance of Marxism, the great harmony of the world would be achieved. As Mao once mentioned, though Kang Youwei wrote the book Great Harmony, he did not and would not find the road to the Great Harmony. To Mao Zedong, socialism was the only way to Great Harmony.

People's Communes in the villages shared something with the earlier "New Village Plan". Bo Yibo (1993:774) claimed that when Mao Zedong was thinking about the People's Commune, his mind was full of the ideas of the western utopian thought and the Chinese great harmony, and the track of the new village can also be perceived in the pattern of People's Commune. In other words, People's Commune was an imagined utopian village in Mao Zedong's mind (Pang, Xianzhi, 1989: 271).

In sum, Mao Zedong's insistence on public ownership came down in a continuous line, from his pursuit of the traditional great harmony in his young age to his advocating of a large-sized-andcollective people's commune after the establishment of the People's Republic of China. Most scholars thought that he changed to advocate private ownership from 1930 to 1953 because of the requirement of the concrete circumstances, but the real reason for his mind change was in 
essence just a tactic but not a strategy. It did not indicate Mao really realized the significance of private ownership in the rural areas of China. History proved that Mao had always been consistent in holding the view of public land ownership.

Mao Zedong's tactics can be perceived in the following example. Before and after the Wayaobao Conference, Mao once emphasized that "it is only after the victory of the national revolution can we talk about how to shift the private land- ownership to public landownership, before that time, do not talk about it again." Yang Kuisong (2012) showed that the following lines in the Directions of May Fourth by the Communist Party of China indicated Mao's thoughts:

Do not hesitate to confiscate the landlords' land to give it to the peasants; Do not hesitate to wipe out the feudal exploitation in the rural areas. We need to try every means to protect the lawful rights of the peasants and encourage their rightful actions, and authorize their gained land and the would-be gained land. The important reason for all these solving the land problem and getting the other work go on well in the liberation area is the key task of our Party, we need to solve this serious problem first.

Another evidence of his real purpose is what he said after the $7^{\text {th }}$ National Congress of CCP: The $7^{\text {th }}$ National Congress of CPC aims to realize the rent and interest reduction, and to give the farmers fair amount of land. ... Only after the solution of this problem, we can continue the severe revolution with the continuous support from the peasants. Guo Mindang is prior to us in more aspects, but they have one weakness, that is, they couldn't solve the land problem, so the masses have no means to live. What they lacked is what we are good at. ... The present situation in China is quite similar to that of the National Revolution in that the peasants ask for land, and we need to make our attitude clear today, that is, whether or not the Communist Party of China will give it to them.

From what Mao said, Yang Kuisong (2012) concluded that what made the central government of CCP make the critical decision of exercising the agrarian reform are from two important considerations. First, under the influence of the policies of CCP, the peasants living in the red base areas had already started to obtain land from the landlords themselves and most areas had already solved the problem, therefore, the central government must give them a response. Secondly, the failure of the revolution in 1927 gave them a serious lesson, that is, the prerequisite of mobilizing the mass is to guarantee the peasants their desired land. Thus, the agrarian policy is the most important issue at present. It is urgent to solve the land problem within the year. If this problem can be solved, soldiers can be enlisted, enemies will be eliminated, and the cities will be built.

Therefore, after the Anti-Japanese War, Mao Zedong's devotion to the land privatization was mainly a tactical decision under the situation both domestic and abroad. Once the situation changed, his original thought returned. This was best evidenced in the cooperative communes after 1953 and the later pure-public-systematized people's communes.

\section{THE CONSEQUENCES OF MAO ZEDONG'S DECISION OF PUBLIC OWNERSHIP}

Young Mao Zedong pursued the Great Harmony with all his heart, and simultaneously he put the theory into practice of the "New Village Plan". Though the plan was not realized because of the war and the utopian nature of the Great Harmony, history proved that Mao never relinquished his thought of a system with public ownership. As soon as the revolution came to 
a victory and Mao possessed the supreme authority over the country, his original thought returned naturally.

To further promote his thought, Mao Zedong first gave up his main proposal of protecting and developing private system, which was published in his paper On New Democracy in 1940. Then he strongly advocated a fast transition towards the socialist system and cooperation, criticizing seriously of Liu Shaoqi for his stubborn insistence on the view of "consolidating the system of new democracy". In 1953, Mao put forward the general line for the transition period and advocated "industrialization and the three reforms in agriculture, handicraft, and commerce with capitalist characteristics". This brought the final end of privatization. In 1956, Mao claimed formally to the outside world that China was already on the road to socialism. From then on, Mao became more energetic to face the new situation, aiming to bring poor China to a prosperous country through the advantages of socialism.

In August, 1958, Mao went to inspect the three provinces of China, Hebei, Henan, and Shandong, addressing that "People's Commune is a good name. It has so many advantages. It connects the workers, farmers, businessmen, students, and soldiers together to form one unified community. Thus, everyone is versatile accomplished. Whenever required, they can behave as a worker, a farmer, a soldier, or a writer". Mao summarized the characteristics of the People's Commune as "large in size and public in nature". It is large in terms of the production scale, and it is public because of its high degree of socialization. Under his promotion, at the end of the October of 1958, most of the villages in China became commune-structured. The original 740,000 cooperative communes were merged to 26,000 People's Communes. To achieve a rapid transfer to a high-degreed public ownership, the properties of various cooperative communes and even of the individuals were merged to be under the unimanagement of the communes. In some places, the living houses of the villagers were torn down and the furniture was taken away to the communes. The communes dining halls were opened across the country, with the intent to have the members of the people's communes eat together without payment. Abolishing the family kitchen was a means of moving to communism.

A typical example is a county named Xushui, Hebei Province. Less than two months after Mao's inspect, The Proposed Regulations on the Supply in the People's Communes was released, cancelling the original salaries for the cadres, clerks and the rewards for the commune members, promising a detailed provision (food, dresses, housing, shoes and socks, soaps, lamps, matches, haircutting, film-watching, funeral ceremonies and etc) for all the people in the county. This brought the people great inconvenience. The masses mocked themselves that "Nothing remained except a pair of chopsticks and a bowl" (He Libo, 2008).

The People's Communes in the rural areas, military-organized, fighting-like, collective-living, are densely covered with egalitarianism and a military color, which violated greatly the economic principles and led naturally to the disappearance of the outside motive (Liu Mei, 2011). What's more, it ignored the nature of the peasants. Implementing the simple policy of public ownership made the peasants lose almost all of their property. And it also severely damaged their initiatives and energy and thus reduced their inner motive to produce. The People's Commune, the utopian society, failed as a result of its ignorance of the nature of the peasants and its departure from the natural principle of social development. As a consequence, people became poorer than before.

Statistics from the original Management Office of the Peoples' Commune of the Agricultural Department showed that in 1978 , the average distribution to the peasants in the country was 
only 74.67 yuan, and the average annual income of the 200,000,000 peasants was less than 50 yuan. The daily income of $112,000,000$ was 0.11 yuan, of some $190,000,000$ was 0.13 yuan, and of some 270,000,000 was 0.14 yuan. From 1957 to 1976, the salary of the workers in China was not increased to a small degree. On the contrary, it decreased. In 1957, the average annual income was 624 yuan, but in 1976, it reduced to 575 yuan (Zeng Peiyan, 1999: 898).

People's poor living conditions can also be perceived in many other aspects. Their life necessities were not adequately supplied. Whenever they wanted to buy something, they had to show the required coupon. Food coupon, which was used for 40 years, was nicknamed "the second currency". The five necessary articles for a family, bike, watch, sewing machine, radio, and camera, only amounted to less than 600 yuan, but could not reach the normal families because few families could pay for them. Their living houses were in bad condition. At the beginning of the reform and opening-up period, among the 1,800,000 families, around half were under the standard. In 119,499 families the three generations would share one room; the number of the families with parents living in the same room with their teenagers amounted to 316,079; in 85,603 families, the teenaged brothers and sisters shared one room; for 44,332 families, the members of two families were even living in the same room; for the 268,650 families, the average living area was 2 square mile. In most houses, there was no dining hall. Several families shared the same kitchen and the same restroom (Cao Pu, 2008).

In July, 1977, Wan Li, the secretary of Anhui Province inspected several places and was shocked by what he saw and heard. Later he recalled, "I couldn't imagine the peasants' poverty. They have not enough food and not fair houses. In some villages, even the doors, windows, tables, and benches are made of earth" (Tian Jiyun, 2006).

\section{CONCLUSION}

Marx once pointed out that only if we enter the communist society, the "three major distinctions" (distinctions between city and country; between industry and agriculture; and between physical and mental labour) can be eliminated. With a strong desire to eliminate the differences between the villages and the cities, and without any consideration of the realities of China, Mao promoted a rapid program of forced socialization of farming and industry, which was destined for a failure.

Mao's failure was first because of the great influence of the traditional Chinese Great Harmony, which was his life-long guiding principle upon the various policies, including the agrarian reforms. Secondly, Mao regarded the communist society as his idealized target, for which he released the general line, started the Great Leap Forward, and proposed the People's Communes. All these means were the prepared bridges to his ideal of a purer communist country. Thirdly, Mao was also a pragmatist besides being an ambitious politician, any policy should be based on the reality or the circumstances of the society. The saddle-shaped thoughts transformation in the land ownership policies was a result of the conflictions between ideal and reality.

In 1978, the Third Plenary Session of the $11^{\text {th }}$ Central Committee of the Chinese Communist Party opened a new historical era. Deng Xiaoping learned a serious lesson from the agrarian reforms in China and gave up the large-scaled and public-featured People's Commune, and introduced the household responsibility system in agriculture, which proved to be fit for the rural areas in China. 


\section{References}

Bo, Yibo. (1993). Rethinking Some Key Policies and Events (Volume 2). Beijing: Central Party School of the Communist Party of China Press.

Cao, Pu. (2008). The Origin of The Reform and Opening-up of China. Theory Reference, 10: 58-61.

Dirlik, Arif. (2012). Mao Zedong in Contemporary Chinese Official Discourse and History. China Perspectives, $2: 17$ 28.

He, Libo. (2008). The Great Leap Forward of Xushui County. History of the Party Through, 6:14-19.

Hu, Chan. (2010). Mao Zedong's Thoughts on the Agrarian Policies. Theory Monthly, 9: 18-20.

Karl, Rebecca E. (2010). Mao Zedong and China in the Twentieth-Century World: A Concise History. Durham, NC: Duke University Press.

Knight, Nick. (2004). Mao Zedong and the Peasants: Class and Power in the Formation of a Revolutionary Strategy. China Report, 40 (1): 49-76.

Lin, Canchu \& Clair, Robin Patric. (2007). Measuring Mao Zedong Thought and Interpreting Organizational Communication in China. Management Communication Quarterly, 20 (4): 395-429. 10.1177/0893318907299177

Liu, Dejun. (2006). An Exploration of the Reasons of Mao Zedong's Wrong Decision in the System of Ownership. Inner Mongolia Social Sciences, 127 (2): 82-84.

Liu, Mei. (2011). Study and Enlightenment on Mao Zedong Thought of Agricultural Egalitarianism. Journal of Northwest A\&F University (Social Science Edition), 11: 59-62.

Long, Guanhua. (2002). A Historical Investigation of Mao Zedong's Solutions of the Peasants' Land Problems. Jiangxi Social Science, 11:110-112.

Mao, Zedong. (1977). The Sellected Works of Mao Zedong (Fifth Volume). Beijing: Renmin Press.

Pang, Xianzhi. (1989). Mao Dedong and His Secretary Tian Jiaying. Beijing: Central Committee Document Press.

Party Literature Research Centre of the CPC Central Committee, CPC Hunan Provincial Committee. The Earlier Works of Mao Zedong editing group. (1990). The Earlier Works of Mao Zedong. Changsha: Hunan Press.

Qin, Hui. (2010). The Talk Show by Qin Hui, Wen Tiejun, and Wang Hui. Gongshi Internet, January 1, 2010.

Selden, Mark. (2006). Jack Gray, Mao Zedong and the Political Economy of Chinese Development. The China Quarterly, 680-685. 10.1017/s0305741006000300

Sun, Zhongshan. (1956). Collected Works of Sun Zhongshan (2). Beijing: Renmin Press.

Tian, Jiyun. (2006). Wan Li: An Outstanding Person in the Reform and Opening up. Yanhuang Chunqiu, 5:1-7.

Wang, Lei. (2012). Mao Zedong's Thoughts and Exercises of the Great Harmony. History of the Party, 9: 21-23.

Wang, Weiguang. (2014). Mao Zedong Is the Great Founder, Explorer, and Pioneer of Socialism with Chinese Characteristics. Social Sciences in China, 35 (3): 5-30. http://dx.doi.org/10.1080/02529203.2014.927089

Wen, Rui. (2004). The Peasants' Issues in Mao Zedong's Eyes. Nanchang: Jiangxi Renmin Press.

Xu, Quanxing. (2003). Mao Zedong and Confucian Thoughts. Beijing: Renmin Press.

Xue, Lili. (2010). Mao Zedong'S Exploration on Land System and Modern Meaning.

J.Shanxi Agric. Univ. (Social Science Edition), 9 (3): 257-260.

Yang, Kuisong, (2012). An Investigation of the Agrarian Revolution of the Communist Party of China after the AntiJapanese War. The History of Jianghuai. 2: 46-66.

Zhang, Fang. (2012). The Span and Tension of Thought: The Vision and Problematiques of Mao Zedong in His Later Years. Journal of Hunan University of Science and Technology (Social Science Edition), 15 (6):17-22.

Zeng,Yanpei. (1999). The Fifty-year Economy of New China. Chinese Planning Press. 